\section{Ampère's Rule}

Beginners are certainly, as Herr Daehne says (NATURE, June 24, p. 168), liable to get a little "mixed" in reference to the above mem. technica; chiefly, I think, for want of s sme idea sufficiently prominent to fix itself on the mind to the exclusion of others.

I have found the following slight modification of the original rule pretty easily remembered and applied.

It may be taken as agreed-

(I) That the head is more important (" more worthy," as the old grammars put it) than the feet.

No one except an acephalous mollusk will deny this; and it is not a fair judge.

(2) That the right hand is more important than the left hand.

The left-handed people are a mere minority (and a nuisance at cricket) ; and minorities are, according to morlern Radical ideas, "une quantité négligeable."

3. That the $\mathrm{N}$-seeking pole is that part of the compass-needle to which attention is mainly directed.

Now,-If a person places himself so as to face the needle, and a current goes from HEAD to foot, the N-SEEKING pole moves to his RIGHT hand.

This is practically the form in which the rule is given in Prof. Balfour Stewart's "Lessons in Physics." One of the small articulated wooden figures used as models in drawing is very useful for illustrating the above rule. Its right arm may be stretched out sideways at right angles to the body, and it may then be held close to the wire in various positions; paper arrows being tied to the latter, to mark direction of current.

Eton College

H. G. MADAN

\section{Halos}

As the atmosphere appears recently to have reassumed in a marked degree some of the peculiar conditions which pertained to it during the time of the great sun glows, I have thought it worth while to send you notes from my diary of some effects observed by me :-

June 14.--Between Io and I I a.m. Complete solar halo of a coppery colour. It lasted more or less distinctly for some time, and gradually faded. I saw no trace of mock suns.

June 23. - Between Io and I0.30 p.m. there was a curious pearly green light in the north-north-east, and some peculiar pearly green clouds (?) floated from north to west. At first I thought this was an auroral display, but probably it was due to the same cause as the "glows."

June 15, 23, 30, July $\mathbf{1}, 2$, and 3-After-glows of the usual pinkish hue.

4, East Street, Lewes, JuIy 3

\section{The Microscope as a Refractometer}

I HAD no idea that the short paper you did me the honour to print on this subject would have led any one to stippose that a claim was made for the discovery of a new principle in physics, or that the microscope was to be used for the first time in questions on refraction.

In so short a space it was impossible to tell over again the tale of progress in this branch of physical optics, and to signalise every worker in the field by name. So much has already been done in the perfecting of optical instruments, that the utmost one can now hope to do is, by a slight improvement here and there, to render them still nore serviceable.

All that was claimed as new in my paper of June 17 was-

(a) The use of the marked slip, structure of cell, superposed cover-glass.

$(\boldsymbol{\beta})$ The measurement of the linear distances between the images by a finely graduated "fine adjustment" screw.

$(\gamma)$ The use of an objective of high amplifying power (a I/20-inch homogeneous immersion may be used if the shoulderpieces of the cell are made with talc, and the cover-glass very thin).

It is of course possible that one or all of these details is not new ; but, in spite of the authorities quoted by Dr. Gladstone to show the previous employment of the microscope in questions of refraction, I still maintain their claims to novelty to be valid; and, even supposing they are not new (which has yet to be shown), my greatest offence is that of independently arriving at a previously known method. And, considering the attention that our most eminent physicists have bestowed upon the subject, the wonder is that this has not more frequently been the case.

As to the efficiency of the method, the only objections urged against it by Dr. Gladstone are : (I) its results cannot be relied upon beyond the third decimal figure; $(2)$ the temperature of the drop of fluid under examination cannot be taken.

As to the first objection, if we take $\mu_{2}, \mu_{2}$ as the tabulated indexes of refraction of two known substances, $\delta$ as representing the difference of distance between the images of the marks viewed through them, and measured by the fine adjustment, $\mu$ and $d$ the corresponding symbols for the fluid under examination, we have the following equation to determine $\mu:-$

$$
\frac{\mu_{2}-\mu_{1}}{\mu-\mu_{1}} \times \frac{\mu}{\mu_{2}}=\frac{\delta}{d} \text {. }
$$

And I see no more reason to limit the exactness of this to the third decimal figure than in the formula used with the hollow prism. Moreover, if a vernier is attached to the fine adjustment the result may be relied upon with still greater accuracy.

(2) As to the temperature. In the case of most fluids this may be taken from the bottle containing the fluid; no grave scientific error will arise from the difference in temperature of a drop of fluid in contact with glass on the stage of the microscope and the same fuid in a glass bottle by its side. In the case of ethers, \&c., the cell may be temporarily sealed.

As to the practical use of the method, the opinion of so known an expert as Dr. Gladstone is of the greatest weight, but as any recognition of the novelty of my method escaped acknowledgment in his notice, I may still hope that its practical use escaped observation also. So thin a stratum of fluid is employed that the index of refraction of black ink may be obtained, a result which would puzzle any one to arrive at who restricted himself to the use of the hollow prism.

That the microscope has been previously used for experiments in refraction no one ever doubted; if Dr. Gladstone, before writing, had had the time to go step by step through my method, he could scarcely have refrained from acknowledging that in its essentials it was hitherto unpublished.

St. Charles's College, Notting Hill, July 3

GORDON THOMPSON

\section{The Bagshot Beds}

As you have given publication (NATURE, July I, p. 2ro) to the abstract of the paper recently reat by Messrs. Monckton and Herries before the Geological Society, in which they assert that their object was to "disprove" the view lately propounded by me, as to the relation of the Bagshot Beds of the London Basin to the London Clay, perhaps you will kindly afford me space to point out to the readers of NATURE (I) that these authors have ignored, in dealing with the question, whole chapters of the evidence upon which my view is based-evidence which is continually accumulating, as two forthcoming papers (one in the press for the Proc. Geol. Assoc., the other in the hands of the editor of the Geol. Mag.) will make manifest enough; (2) that in directing their attention merely to sections at the outcrop of the bed; they have added little, if anything, substantially, to that on which the old view was based, while the lithological distinctions of the Upper and Lower Bagshot Beds (where the latter have been for ages undergoing oxidation) are not sufficiently marked to furnish, in disconnected sections, evidence which can be anything more than, to say the least, equivocal.

Wellington College, Berks, July 3

\section{The Enemies of the Frog}

IN connection with this subject the following incident may be of interest to some of your readers. One day, near the kitchen area, an unusual noise was heard : it seemed like the mewing of a cat combined with a well-sustained whistle. On going to the spot, it was found that the noise proceeded from a cat and a frog, but it was difficult to decide from zohich of the two. Every time the cat touched the frog the sound was produced and the frog hopped away. The cat exhibited in his attitudes and motions a sort of enjoyment mingled with awe. He would just touch the frog very gently with the tips of his paws, then watch it most attentively, and when the frog would emit its peculiar loud squeak-not the usual croak-he would give a sudden bound, as if both suprised and amused; but he never 